\title{
Yield and Fruit Quality Traits of Rambutan Cultivars Grafted onto a Common Rootstock and Grown at Two Locations in Puerto Rico
}

\author{
Ricardo Goenaga ${ }^{1}$ and David Jenkins
}

ADDITIONAL INDEX wORDs. soluble solids concentration, Nephelium lappaceum, yield

SUMMARY. The globalization of the economy, increased ethnic diversity, and a greater demand for healthy and more diverse food products have opened a window of opportunity for the commercial production and marketing of tropical fruit, including rambutan (Nephelium lappaceum). There is a lack of formal experimentation to determine yield performance and fruit quality traits of rambutan cultivars. Eight rambutan cultivars (Benjai, Gula Batu, Jitlee, R-134, R-156Y, R-162, R-167, and Rongren) grown on an Ultisol and an Oxisol soils were evaluated for 5 years at Corozal and Isabela, $\mathrm{PR}$, respectively. There was a significant difference in the number and weight of fruit per hectare between locations, averaging 415,103 fruit/ha and $13,826 \mathrm{~kg} \cdot \mathrm{ha}^{-1}$, respectively, at Corozal and 167,504 fruit/ha and $5149 \mathrm{~kg} \cdot \mathrm{ha}^{-1}$, respectively, at Isabela. At Corozal, 'R162' had the highest 5-year mean for number and weight of fruit per hectare, but this cultivar was not significantly different from the rest except for 'Benjai' and 'R-156Y', which had significantly lower values. At Isabela, cultivars Gula Batu and R-162 had significantly higher number of fruit per hectare but the latter was not different from 'Benjai'. Overall, there were no differences in soluble solids concentration except for cultivars Gula Batu and R-156Y, which had significantly lower values at both locations. Cultivar R-162 had higher number and weight of fruit per hectare and high soluble solids concentration at both locations, making it suitable for planting in various agroenvironments particularly on Ultisols typical of the humid tropics.

$\mathrm{T}$ he globalization of the economy and the increased demand for healthy and more diverse food products have opened a window of opportunity for the commercial production and marketing of nontraditional tropical/subtropical fruit crops. Rambutan is native to Malaysia and Indonesia and is a member of the Sapindaceae family (Tindall, 1994). The tree is strictly tropical and adapts to well-drained, clayey acid soils under a rainfall distribution of $\approx 2000 \mathrm{~mm}$ per year (Goenaga, 2011; Tindall, 1994). The edible portion of the fruit is a fleshy, translucent white sarcotesta that arises from an integument surrounding a single oblong seed. In freestone cultivars, the sarcostesta and integument come freely away from the seed, a desired characteristic; in "clingstone" cultivars, they are more difficult to separate (O'Hare, 2001). The existence of the West Indian fruit fly (Anastrepha obliqua) in Puerto Rico is an obstacle to the export of many fruit. However, an extensive survey of ripe fruit from the field did not recover any rambutan infested with this fruit fly, nor did any adult fruit flies develop from ripe rambutan fruit with the peel partially removed and exposed to fecund and fertile female fruit flies, demonstrating that the fruit is not a host to this fruit fly and making its exportation possible to locations where it is not present (Jenkins and Goenaga, 2008).

There is little information available on total production area of rambutan worldwide. Indonesia, Thailand, and Malaysia are the largest producers of rambutan, with total production areas of $90,000,86,440$, and 43,000 ha, respectively (Salakpetch, 2000; Zee, et al., 1998). Hawaii and Puerto Rico are the only production areas in the United States with $\approx 110$ ha.

Commonly used cultivars for commercial production include R-134, R156, R-162, R-167, Gula Batu (Malaysia), Benjai, Lebakbulus (Indonesia), Seechompoo, Rongren (Thailand), and Jitlee (Singapore) (Tindall, 1994). Production of fully matured trees of these cultivars is estimated to range from 60 to $300 \mathrm{~kg} \cdot \mathrm{ha}^{-1}$ (Diczbalis, 2004; Tindall, 1994). However, results from replicated field trials to evaluate these and other cultivars are very limited. The purpose of this study was to evaluate yield performance and fruit quality traits of eight rambutan cultivars grown in two agroenvironments.

\section{Materials and methods}

This study was conducted in Puerto Rico at the U.S. Department of Agriculture, Agricultural Research Service Research Farm in Isabela (Coto clay: clayey, kaolinitic isohyperthermic Typic Hapludox) and at the Corozal Agricultural Experiment Station of the University of Puerto Rico (Corozal clay: clayey, mixed, isohyperthermic Aquic Haplohumults). Soil and climatic characteristics are described in Tables 1 and 2. Soil samples from each site were taken $\approx 2$ months before planting by taking 15 borings at a depth of $0-25 \mathrm{~cm}$ from each of the 10 projected cultivar rows. Samples were air-dried and passed through a 20 -mesh screen. Soil $\mathrm{pH}$ in water and $0.01 \mathrm{M}$ calcium chloride (1 soil : 2

USDA-ARS, Tropical Agriculture Research Station, 2200 P.A. Campos Avenue, Suite 201, Mayaguez, PR 00680-5470

Mention of trade names or commercial products in this publication is solely for the purpose of providing specific information and does not imply recommendation or endorsesment of the U.S. Department of Agriculture.

The authors thank Nicolás Díaz (deceased), Angel Marrero, José Luis Rodríguez, Edmundo Rivera, Tomás Miranda, and Pablo Ríos for their excellent field assistance and Francis Zee for assistance in obtaining the plant material and useful suggestions.

'Corresponding author. E-mail: Ricardo.Goenaga@ ars.usda.gov.

\begin{tabular}{llll}
\hline $\begin{array}{l}\text { Units } \\
\begin{array}{l}\text { To convert U.S. to SI, } \\
\text { multiply by }\end{array}\end{array}$ & U.S. unit & SI unit & $\begin{array}{l}\text { To convert SI to U.S., } \\
\text { multiply by }\end{array}$ \\
\hline 0.4047 & $\mathrm{acre}(\mathrm{s})$ & $\mathrm{ha}$ & 2.4711 \\
1 & $\mathrm{cbar}$ & $\mathrm{kPa}$ & 1 \\
0.3048 & $\mathrm{ft}$ & $\mathrm{m}$ & 3.2808 \\
3.7854 & $\mathrm{gal}$ & $\mathrm{L}$ & 0.2642 \\
2.54 & $\mathrm{inch}(\mathrm{es})$ & $\mathrm{cm}$ & 0.3937 \\
1.1209 & $\mathrm{lb} / \mathrm{acre}$ & $\mathrm{kg} \cdot \mathrm{ha}^{-1}$ & 0.8922 \\
28.3495 & $\mathrm{Oz}$ & $\mathrm{g}$ & 0.0353 \\
1 & $\mathrm{ppm}$ & $\mathrm{mg} \cdot \mathrm{kg}^{-1}$ & 1 \\
6.8948 & $\mathrm{psi}$ & $\mathrm{kPa}$ & 0.1450 \\
$\left({ }^{\circ} \mathrm{F}-32\right) \div 1.8$ & ${ }^{\circ} \mathrm{F}$ & ${ }^{\circ} \mathrm{C}$ & $\left(1.8 \times{ }^{\circ} \mathrm{C}\right)+32$ \\
& & &
\end{tabular}


water) were measured using a glass electrode. Exchangeable cations (K, $\mathrm{Mg}$, and $\mathrm{Ca}$ ) were extracted with neutral $1 \mathrm{~N}$ ammonium acetate and determined by atomic absorption spectroscopy (Sumner and Miller, 2007). Phosphorus was determined by extracting with $1 \mathrm{~N}$ ammonium fluoride and $0.5 \mathrm{~N}$ hydrochloric acid and determined colorimetrically at $882 \mathrm{~nm}$ using the ascorbic acid method (Benton, 2001). Organic carbon was determined by the Walkley-Black method (Nelson and Sommers, 2007). Soil ammonium and nitrate were determined by steam distillation (Mulvaney, 2007).

Six-month-old trees of cultivars Benjai, Gula Batu, Jitlee, R-134, R156 (yellow), R-162, R-167, and Rongren grafted onto ' $\mathrm{R}-167$ ' rootstocks were transplanted to the field on 21 July 1999 (Isabela) and on 2 Sept. 1999 (Corozal) and were arranged in a randomized completeblock design with five replications at each location. Representative fruit from each cultivar are shown in Fig. 1. Planting holes $\approx 1.5 \mathrm{ft}$ deep were dug with an auger connected by a drive shaft to the power-take-off unit of a tractor. On transplanting, each plant received $11 \mathrm{~g}$ granular $\mathrm{P}$ provided in the form of triple superphosphate. Before transplanting, the soil was chisel-plowed to a depth of $\approx 90 \mathrm{~cm}$. Within a replication, plots for each cultivar contained three trees spaced $20 \mathrm{ft}$ apart and $20 \mathrm{ft}$ between adjacent rows in a triangular array. The experiments were surrounded by two guard rows of 'R-134'seedlings. Irrigation was provided with spinner jets (model DXMAG368X; Maxijet, Dundee, FL) spaced $20 \mathrm{ft}$ apart and providing 13.5 $\mathrm{gal} / \mathrm{h}$ at $20 \mathrm{psi}$ when the soil water tension at a depth of $30 \mathrm{~cm}$ exceeded $50 \mathrm{kPa}$. Fertilization was provided every 3 months using a $15 \mathrm{~N}-2.2 \mathrm{P}-$ $16.3 \mathrm{~K}-1.8 \mathrm{Mg}$ commercial mixture at a rate of 100,200 , and $269 \mathrm{~kg} \cdot \mathrm{ha}^{-1}$ until 2002, 2006, and 2009, respectively. Herbicide (glyphosate) for weed control was applied only in strips within the planting row. Weeds between rows were controlled with a tractor mower. Saf-T-Side oil spray (Brandt Consolidated, Springfield, IL) was occasionally used during rainy periods to control sooty mold.

Harvests were initiated in Aug. 2005 at both locations. At this time, grafted trees were $\approx 6.5$ years old. At harvest, telescopic long reach pruners

Table 1. Average preplant soil characteristics at two rambutan test sites in Puerto Rico measured to a depth of $25 \mathrm{~cm}$ (9.84 inches).

\begin{tabular}{lcc}
\hline Soil characteristics & Corozal (Ultisol) & Isabela (Oxisol) \\
\hline $\mathrm{pH}$ in water & 4.2 & 6.0 \\
$\mathrm{pH}$ in calcium chloride & 3.7 & 5.1 \\
Ammonium nitrogen $\left(\mathrm{mg} \cdot \mathrm{kg}^{-1}\right)^{\mathrm{z}}$ & 13.0 & 37.5 \\
Nitrate nitrogen $\left(\mathrm{mg} \cdot \mathrm{kg}^{-1}\right)$ & 41 & 21 \\
Organic carbon $(\%)$ & 1.99 & 1.27 \\
Phosphorous $\left(\mathrm{mg} \cdot \mathrm{kg}^{-1}\right)$ & 6.00 & 63.00 \\
Potassium $\left(\mathrm{mg} \cdot \mathrm{kg}^{-1}\right)$ & 244 & 500 \\
Calcium $\left(\mathrm{mg} \cdot \mathrm{kg}^{-1}\right)$ & 993 & 732 \\
Magnesium $\left(\mathrm{mg}^{\mathrm{k}} \mathrm{kg}^{-1}\right)$ & 64 & 133 \\
\hline
\end{tabular}

${ }^{2} 1 \mathrm{mg} \cdot \mathrm{kg}^{-1}=1 \mathrm{ppm}$.

Table 2. Weather data at two rambutan test sites in Puerto Rico (2005-2009).

\begin{tabular}{lcc}
\hline Site characteristics & Corozal (Ultisol) & Isabela (Oxisol) \\
\hline Total rainfall $(\mathrm{cm})^{\mathrm{z}}$ & 964 & 890 \\
Total evaporation $(\mathrm{cm})$ & 696 & 808 \\
Maximum temperature $\left({ }^{\circ} \mathrm{C}\right)^{\mathrm{z}}$ & 30.6 & 29.3 \\
Minimum temperature $\left({ }^{\circ} \mathrm{C}\right)$ & 19.9 & 21.8 \\
Elevation $(\mathrm{m})^{\mathrm{z}}$ & 195 & 126 \\
\hline
\end{tabular}

${ }^{2} 1 \mathrm{~cm}=0.3937$ inch, $\left(1.8 \times{ }^{\circ} \mathrm{C}\right)+32={ }^{\circ} \mathrm{F}, 1 \mathrm{~m}=3.2808 \mathrm{ft}$.

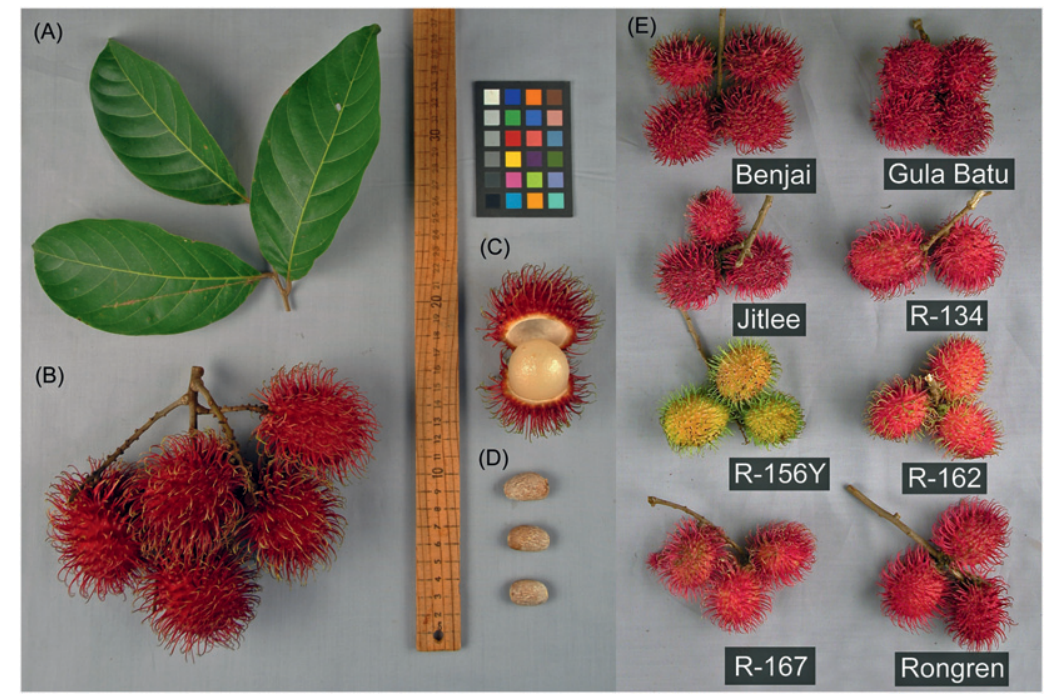

Fig. 1. Rambutan fruit components and cultivar differences: (A) leaves, (B) fruit cluster, (C) opened fruit with pulp (aril) exposed, (D) seeds, and (E) fruit clusters of cultivars used in the experiment.

(model 160ZR-3.0-5; ARS, Osaka, Japan) were used to cut fruit clusters on terminal ends of the branches from each of the three trees per replication and cultivar. The weight of fruit clusters attached to stem pieces was recorded in the field (fruit cluster yield). Fruit clusters were then brought to the laboratory where they were separated from stems, counted, and weighed again (fruit yield). Fruit from each tree were then composited by replication and cultivar. Representative fruit totaling $10 \%$ of those harvested were then used to determine soluble solids with a temperature-compensated digital refractometer (PAL1; Atago, Tokyo, Japan) l d after harvest. These fruit were also used to determine rind (rind plus spinterns), pulp, and seed weight after cutting fruit with a sharp knife and separating parts. Flowering normally occurred during July to September 
and fruit harvested from November to January; between three and five harvests were made during the harvesting period.

Analysis of variance was carried out using the GLM procedure of SAS (release 9.1 for Windows; SAS Institute, Cary, NC). After significant $F$ test at $P \leq 0.05$, mean separation was performed with the least significant difference test.

\section{Results and discussion}

Year, location, cultivar, and the year $\times$ location interaction showed highly significant effects $(P \leq 0.01)$ on all fruit parameters measured in the study (Table 3 ). The location $\times$ cultivar interaction was not significant, indicating that cultivars responded similarly at each location. The year $\times$ cultivar interaction was significant for all yield parameters.
Overall, cultivars exhibited an increase in fruit number and yield during the first 3-4 years of production (Table 4). This response was expected as trees increased in age. However, the magnitude of this response varied among cultivars as expected by the significant year $\times$ cultivar interaction (Table 3). At Corozal, most cultivars had the highest number of fruit and yield during the fourth and fifth year of production, whereas at Isabela, this occurred either in the third or fifth year. At Corozal, 'R-167' was the only cultivar that had an increase in the number of fruit and yield throughout the whole experimental period (Table 4). This cultivar was used as a rootstock, and scion/rootstock compatibility may explain higher productivity. However, if this was the case, it does not explain the yield decline at Isabela in 2008. Further, there was no visual indication of scion/rootstock incompatibility. In 2008, fruit number and yield of cultivars at Isabela declined by an average of $57.5 \%$ and $56 \%$, respectively, as compared with 2007 (Table 4). Rainfall at Isabela in 2008 was $20 \%$ below the historical mean and extremely windy, particularly during the months of February, March, and April. These weather conditions may have prevented trees from building up carbohydrate reserves and recover from the 2007 harvest. Rambutan is known for its lack of tolerance to windy conditions (Tindall, 1994; Zee, 1993 ).

At Corozal, 'R-162' had the highest 5-year mean for number and yield of fruit; however, these variables were not significantly different from other cultivars except Benjai and R156Y, which had significantly lower number and yield of fruit (Table 4).

Table 3. Number of fruit, fruit yield, and fruit weight components and total soluble solids of eight rambutan cultivars planted at two locations in Puerto Rico. Values are means of five replications and 5 years (2005-2009).

\begin{tabular}{|c|c|c|c|c|c|c|c|c|c|}
\hline Location & Cultivar & $\begin{array}{c}\text { Fruit } \\
(\text { no. } / \text { ha })^{\mathrm{z}}\end{array}$ & $\begin{array}{c}\text { Fruit cluster } \\
\text { yield }\left(\mathrm{kg} \cdot \mathrm{ha}^{-1}\right)^{\mathrm{z}}\end{array}$ & $\begin{array}{c}\text { Fruit yield } \\
\left(\mathrm{kg} \cdot \mathrm{ha}^{-1}\right)\end{array}$ & $\begin{array}{l}\text { Fruit soluble } \\
\text { solids (\%) }\end{array}$ & $\begin{array}{l}\text { Individual } \\
\text { fruit wt }(\mathrm{g})^{\mathrm{z}}\end{array}$ & $\begin{array}{l}\text { Pulp } \\
\text { wt (g) }\end{array}$ & $\begin{array}{c}\text { Seed } \\
\text { wt }(g)\end{array}$ & $\begin{array}{l}\text { Rind } \\
\text { wt (g) }\end{array}$ \\
\hline \multirow[t]{8}{*}{ Corozal } & Benjai & 371,765 & 13,168 & 12,031 & 20.6 & 33.7 & 15.9 & 2.1 & 15.6 \\
\hline & Gula Batu & 431,487 & 15,325 & 14,026 & 18.8 & 33.0 & 14.8 & 1.8 & 16.5 \\
\hline & Jitlee & 453,850 & 16,462 & 15,171 & 20.7 & 35.3 & 16.3 & 2.2 & 16.5 \\
\hline & R-134 & 448,670 & 16,210 & 14,873 & 20.6 & 33.2 & 15.8 & 2.1 & 15.2 \\
\hline & R-156Y & 258,236 & 10,195 & 9,520 & 19.5 & 38.5 & 23.8 & 2.2 & 12.6 \\
\hline & Rongren & 416,774 & 15,252 & 13,978 & 20.5 & 36.1 & 19.7 & 2.1 & 14.2 \\
\hline & Average & 415,103 & 15,079 & 13,826 & 20.3 & 34.6 & 17.3 & 2.1 & 15.1 \\
\hline & $\operatorname{LSD}^{\mathrm{y}}(0.05)$ & 76,348 & 2,787 & 2,626 & 0.46 & 1.9 & 1.1 & 0.11 & 1.4 \\
\hline \multirow[t]{13}{*}{ Isabela } & Benjai & 183,379 & 5,840 & 5,452 & 21.9 & 35.0 & 17.1 & 2.3 & 15.6 \\
\hline & Gula Batu & 230,017 & 7,282 & 6,710 & 20.5 & 34.0 & 16.4 & 1.9 & 16.7 \\
\hline & R-167 & 159,244 & 5,303 & 4,955 & 21.9 & 36.3 & 17.0 & 2.5 & 16.6 \\
\hline & Rongren & 152,573 & 5,019 & 4,744 & 22.0 & 34.4 & 17.7 & 1.8 & 14.9 \\
\hline & Average & 167,504 & 5,511 & 5,149 & 21.8 & 37.0 & 18.5 & 2.3 & 16.3 \\
\hline & LSD $(0.05)$ & 45,694 & 1,530 & 1,452 & 0.46 & 2.2 & 5.1 & 0.76 & 4.8 \\
\hline & $\operatorname{LSD}(0.05)^{\mathrm{x}}$ & 22,713 & 798 & 746 & 0.18 & 2.1 & 2.0 & 0.16 & 0.77 \\
\hline & Year $(\mathrm{Y})$ & $\star * *$ & $* * *$ & $* * *$ & $* * *$ & $* *$ & ** & * & $* *$ \\
\hline & Location (L) & $* * *$ & $* * *$ & $* * *$ & $* * *$ & * & NS & ** & $*$ \\
\hline & $\mathrm{Y} \times \mathrm{L}$ & $* * *$ & $* * *$ & $* * *$ & $* * *$ & NS & * & * & * \\
\hline & Cultivar (C) & $* * *$ & $* * *$ & $* * *$ & $* * *$ & $* * *$ & $* * *$ & * & NS \\
\hline & $\mathrm{L} \times \mathrm{C}$ & NS & NS & NS & NS & NS & NS & NS & * \\
\hline & $\mathrm{Y} \times \mathrm{C}$ & $* * *$ & $* * *$ & $* * *$ & NS & $* *$ & $*$ & $*$ & ** \\
\hline
\end{tabular}

${ }^{\mathrm{z}} 1 \mathrm{fruit} / \mathrm{ha}=0.4047$ fruit $/$ acre, $1 \mathrm{~kg} \cdot \mathrm{ha}^{-1}=0.8922 \mathrm{lb} / \mathrm{acre}, \mathrm{lg}=0.0353 \mathrm{oz}$.

yeast significant difference at $P=0.05$.

${ }^{\mathrm{x}}$ Compares means among locations.

Ns, ${ }^{*},{ }^{* *},{ }^{* *}$ Nonsignificant or significant at $P \leq 0.05,0.01$, or 0.001 , respectively. 


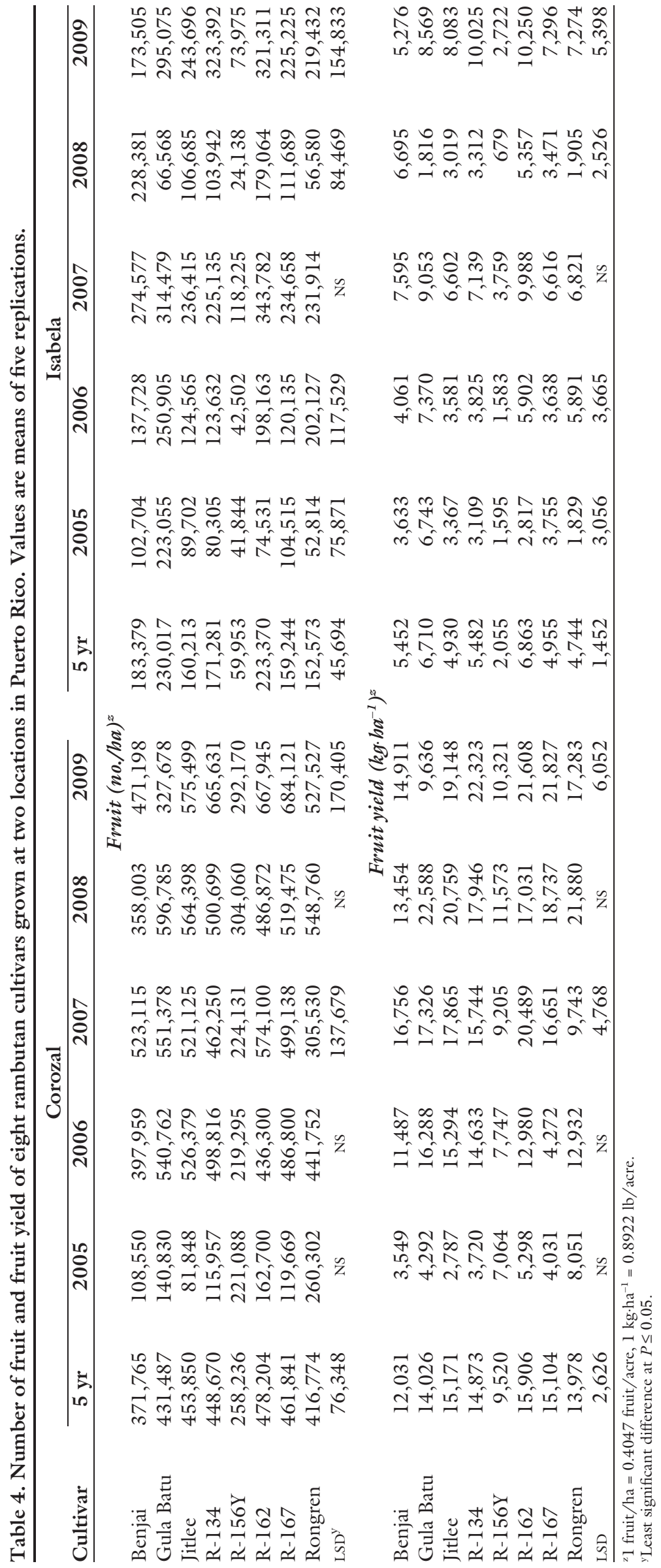

At Isabela, cultivars Gula Batu and R162 had significantly higher number of fruit but the latter was not different from 'Benjai'. Cultivars R-162 and Gula Batu had the highest fruit yield per hectare at Isabela, but these did not differ statistically from 'R134'and 'Benjai' (Table 4). At both locations, 'Gula Batu' had the highest number of fruit and yield in 2 of the 5 years the experiment lasted. However, this cultivar showed a dramatic decline in production in 2009 at Corozal and in 2008 at Isabela after registering very high yield in the year before (Table 4). At both locations, total number and yield of fruit was significantly lower in ' $\mathrm{R}-156 \mathrm{Y}$ '.

Total number and yield of fruit were significantly different between locations, with more fruit produced at Corozal $(415,103$ fruit/ha) than at Isabela (167,504 fruit/ha) (Table 3). A possible explanation for why more fruit were produced at Corozal than at Isabela may be that this site is less windy than Isabela and it received more evenly distributed rainfall. In addition, soil $\mathrm{pH}$ at Corozal is acidic (Table 1 ) and rambutan has been shown to thrive on acid soils (Goenaga, 2011).

Although rambutan fruit are normally sold as individual units packed in plastic clamshells in groups of 8-10 fruit, the fruit is also sold in clusters in farmers' markets. In this instance, the fruit remains attached to small stem sections after harvest. In this study, we found that on average, between $7 \%$ and $8 \%$ of the harvested clusters were composed of stem pieces (Table 3 ). Marketing fruit in clusters has the advantage of being less laborious and minimizing fruit damage because detaching stems from fruit may cause rupturing of the skin. However, because of bulkiness, marketing fruit as clusters make it unsuitable for packaging in clamshells. Clamshells can be refrigerated to reduce moisture loss of fruit and increase shelf life. Moisture loss through fruit spinterns can be significant. Studies have shown that, after storing rambutan for $6 \mathrm{~d}$ at an ambient temperature of $27^{\circ} \mathrm{C}$, the fruit lost $45 \%$ in weight as compared with $29 \%$ when stored at $10{ }^{\circ} \mathrm{C}$. When fruit was stored for the same period in perforated bags at $10{ }^{\circ} \mathrm{C}$, weight loss was only 2.8\% (Mendoza et al., 1972). Therefore, marketing rambutan in fruit clusters is not conducive to prolonged shelf life. 
Average individual fruit weight was significantly different between locations (Table 3 ). At both sites, ' $R$ $156 Y^{\prime}$ produced fewer fruit but individual fruit weight was significantly higher, averaging $43.8 \mathrm{~g}$. Small and no significant differences in individual fruit weight were found at Corozal and Isabela, respectively, among the rest of the cultivars. The average individual fruit weight $(35.8 \mathrm{~g})$ of the cultivars used in this study was higher than that of 10 selected rambutan cultivars from the Association of South East Asian Nations, which averaged $27.4 \mathrm{~g}$ (Tindall, 1994).

At both locations, pulp (aril) weight was significantly higher in fruit of 'R-156Y' (Table 3). There were few significant differences in fruit pulp weight among the rest of the cultivars except, for Rongren at Corozal, which had higher pulp weight than other cultivars, but lower pulp weight than 'R-156Y' (Table 3 ). As a percentage of total fruit weight, average pulp weight among cultivars at both locations was $49.7 \%$, with pulp weight of ' $\mathrm{R}-156 \mathrm{Y}$ ' averaging $59.6 \%$. At both locations, rind and seed weight did not vary much among cultivars, with these fruit components averaging $44.1 \%$ and $6.2 \%$, respectively, of the total fruit weight.

In this study, eight rambutan cultivars were evaluated for the first time at two locations during 5 years of production. These cultivars had significantly higher yields at Corozal (Ultisol) than at Isabela (Oxisol). Cultivars R-162, R-167, Jitlee, and R134 had consistent high production of fruit, high yield, and high soluble solids concentration values, making these cultivars suitable for planting on Ultisol soils. Cultivar R-162 also performed among the best at Isabela (Oxisol), demonstrating more adaptability for planting at various agroenvironments. Cultivar Gula Batu performed relatively well at Corozal and produced more fruit at Isabela, but it had significantly lower soluble solids concentration values than the rest of the cultivars (Table 3 ) at both locations. The pulp of this cultivar also adheres to the seed (clingstone), which is not a desired characteristic. Nevertheless, during this study, 'Gula Batu' was found to have some tolerance to the stem canker caused by the fungus Dolabra nepheliae (Rossman et al., 2007, 2010) and, hence, can be an alternative for areas where this fungus is a serious problem. Currently, there is no effective fungicidal treatment against this fungus.

\section{Literature cited}

Benton, J.J. 2001. Laboratory guide for conducting soil tests and plant analysis. CRC Press, Boca Raton, FL.

Diczbalis, Y. 2004. Rambutan, p. 191-197. In: S. Salvin, M. Bourke, and T. Byrne (eds.). The new crop industries handbook. Rural Industries Research and Development Corp., Canberra, Australia.

Goenaga, R. 2011. Dry matter production and leaf elemental concentrations of rambutan grown on an acid Ultisol. J. Plant Nutrition 34:753-761.

Jenkins, D. and R. Goenaga. 2008. Host status of litchi and rambutan to the west indian fruit fly (Diptera: Tephritidae). Fla. Entomol. 91:228-231.

Mendoza, D.B., E.R.B. Pantastico, and F.B. Javier. 1972. Storage and handling of rambutan (Nephelium lappaceum L.). Philippines Agr. 55:322-332.

Mulvaney, R.L. 2007. Nitrogen: Inorganic forms, p. 1123-1139. In: D.L. Sparks (ed.). Methods of soil analysis. Part 3. Chemical methods. Soil Sci. Soc. Amer., Amer. Soc. Agron., Madison, WI.
Nelson, D.W. and L.E. Sommers. 2007. Total carbon, organic carbon and organic matter, p. 983-998. In: D.L. Sparks (ed.). Methods of soil analysis. Part 3. Chemical methods. Soil Sci. Soc. Amer., Amer. Soc. Agron., Madison, WI.

O'Hare, T.J. 2001. Rambutan, p. 309321. In: S.K. Mitra (ed.). Postharvest physiology and storage of tropical and subtropical fruits. CABI Publishing, Wallingford, UK.

Rossman, A.Y., C.L. Schoch, D.F. Farr, K. Nishijima, L. Keith, and R. Goenaga. 2010. Dolabra nepheliae on rambutan and lychee represents a novel lineage of phytopathogenic Eurotiomycetes. Mycoscience 51:300-309.

Rossman, A.Y., R. Goenaga, and L. Keith. 2007. First report of Dolabra nepheliae on rambutan and litchi in Hawaii and Puerto Rico. Plant Dis. 91:1685.

Salakpetch, S. 2000. Rambutan production in Thailand, p. 13-17. In: M.A. Nagao (ed.). Proc. X Annu. Intl. Trop. Fruit Conf., Hilo, HI 20-22 Oct. 2000.

Sumner, M.E. and W.P. Miller. 2007. Cation exchange capacity and exchange coefficients, p. 1201-1221. In: D.L. Sparks (ed.). Methods of soil analysis. Part 3. Chemical methods. Soil Sci. Soc. Amer., Amer. Soc. Agron., Madison, WI.

Tindall, H.D. 1994. Rambutan cultivation. FAO Plant Production and Protection Paper 121. Food and Agriculture Organization of the United Nations, Rome, Italy.

Zee, F.T. 1993. Rambutan and pili nuts: Potential crops for Hawaii, p. 461-465. In: J. Janick and J.E. Simon (eds.). New crops, Wiley, New York.

Zee, F.T.P., H.T. Chan, and C.R. Yen. 1998. Lychee, longan, rambutan and pulasan, p. 290-335. In: P.E. Shaw, H.T. Chan, and S. Nagy (eds.). Tropical and subtropical fruits. AgScience, Auburndale, FL. 